Volume 8. No. 9, September 2020

International Journal of Emerging Trends in Engineering Research

Available Online at http://www.warse.org/IJETER/static/pdf/file/ijeter192892020.pdf

https://doi.org/10.30534/ijeter/2020/192892020

\title{
Bioleaching of Arsenic from Realgar Using Leptosprillum ferriphilum: Effect of Ferrous Iron and Kinetics Aspects
}

\author{
Sundramurthy Venkatesa Prabhu ${ }^{1 *}$, Bashyam Sasikumar ${ }^{2}$ \\ ${ }^{1}$ Department of Chemical Engineering, Addis Ababa Science and Technology University, Addis Ababa, Ethiopia, \\ venkatchemdata@gmail.com \\ ${ }^{2}$ Faculty of Mechanical and Production Engineering, Arba Minch University, Arba Minch, Ethiopia
}

\begin{abstract}
The eco-friendly technique of metal leaching, called, bioleaching is gaining huge interest in bio-hydrometallurgical process. This method is a promising technology for extraction of several valuable metals. In this investigation, biological extraction of arsenic (As) from realgar was focused. The bacteria, Leptospirillum ferriphilum was used as microbial agent. The shaker flask experiments were done at $180 \mathrm{rpm}$, with $0.3 \%(\mathrm{w} / \mathrm{v})$ pulp density. The temperature and initial $\mathrm{pH}$ were maintained at $313 \mathrm{~K}$ and 1.5 , respectively. The concentration of $\mathrm{Fe}(\mathrm{II})$ was varied from 1-12 g/L. The influence of Fe(II) bioleaching of arsenic was studied. The experiment results explicated that arsenic bioleaching were greatly affected by $\mathrm{Fe}$ (II) concentration used in the media. After 30 days, it was observed that $75.42 \%$ of arsenic was extracted at maximum when using $6 \mathrm{~g} / \mathrm{L}$ of $\mathrm{Fe}(\mathrm{II})$. Kinetics on the bioleaching data were observed to be the maximum rate constant value $\left(1.4643 \mathrm{~d}^{-1}\right)$ was attained while using the optimum concentration of $\mathrm{Fe}$ (II). Shrinking core model (SCM) was used to identify the rate-limiting step. From the study, it was observed that the bioleaching rate of arsenic was controlled by diffusion through ash layer.
\end{abstract}

Key words: Arsenic, Bacteria, Fe(II), Kinetics, Leaching, Leptospirillum ferriphilum, Realgar, Rate controlling step.

\section{INTRODUCTION}

Arsenic (As) is one of the important minerals that found abundance at the earth's crust. It has been observed in more than two hundred different minerals. Most of the As quantity is exist in the form of sulfide ores such as arsenopyrite (FeAsS), orpiment $\left(\mathrm{As}_{2} \mathrm{~S}_{3}\right)$, and realgar $\left(\mathrm{As}_{2} \mathrm{~S}_{2}\right)$ [1]. As can cause poisoning for humans to death if As is swallowed beyond a certain limit since it is readily absorbed. It seriously affects instinctive system, nervous and heart. Exposure of As mainly via the air breathed in can pose to serious threat to induce cancers. However, As can be applied at wide application in various fields. Insects such as fungi and bacteria are eradicated by the As due to its heavy toxicity that led to its potential use as preservatives, in specific, for wood. It is also used for taxonomic sample preservation. As is known to be good n-type dopant in semiconductor devices. Gallium arsenide, the optoelectronic compound of As, is most extensive semiconductor used after doped silicon. As is extracted from the environment by different methods. The extracted As can be subjected in to further appropriate treatment and used for various commercial applications. Realgar is one of the chief sulfide minerals of As that contains major quantity of As. In mordent medical world, realgar is used for the treatment to relapse the chronic myelogenous leukemia and acute promyelocytic leukemia when the dosage of soluble As is in judicious quantity. It is also exploited for curing psoriasis, abdominal pains, and burns [2]. Hence, realgar can be widely used if the concentration of As is reduced to appropriate level [3].

Realgar is the most important source of As. Realgar is commonly subjected into chemical or biological extraction to leach the As. Chemical leaching is expensive and cause environmental pollution. Therefore, biological leaching (bioleaching) is gained huge interest as an alternative method against chemical method $[4,5]$. Bioleaching principle is the metal extraction using pure or consortium of sulphur oxidizing and/or iron-oxidizing microbes [6, 7]. Bioleaching can be potential leaching method for As because its cost effectiveness and environmentally-friendly process [8]. In the bioleaching process, $\mathrm{Fe}(\mathrm{II})$ is oxidized to $\mathrm{Fe}(\mathrm{III})$ by iron-oxidizing bacteria (IOB). The biologically produced ferric iron is acted as a leaching agent of the sulfide minerals to solubilize the target metals. This mechanism is explicated in following equations for the bioleaching of realgar to extract As [9].

$2 \mathrm{Fe}^{2+}+4 \mathrm{H}^{+}+\mathrm{O}_{2} \longrightarrow \mathrm{IOB}$
$\mathrm{As}_{2} \mathrm{~S}_{2}+2 \mathrm{Fe}^{3+} \longrightarrow 4 \mathrm{Fe}^{3+}+2 \mathrm{H}_{2} \mathrm{O} \quad \ldots$ (1)
$2 \mathrm{As}^{3+}+2 \mathrm{~S}^{\circ}+6 \mathrm{Fe}^{2+} \ldots$ (2)

Acidithiobacillus and Leptospirillum are the extensively employed genus in bioleaching of different metals. 
Sundramurthy Venkatesa Prabhu et al., International Journal of Emerging Trends in Engineering Research, 8(9), September 2020, 6080 - 6084

Acidithiobacillus ferrooxidans, A. thiooxidans, A. caldus, and Leptospirillum ferrooxidans are found to be most employed bacteria in bioleaching process. Among them, Acidithiobacillus ferrooxidans and A. thiooxidans are observed to be most successful microorganisms for the bioleaching process $[10,11]$. Leptospirillum ferriphilum is the one of the potential microorganisms under the genus Leptospirillum. So far, a few works have been carried out using Leptospirillum ferriphilum [12] and researchers showing huge interest on $L$. ferriphilum as it can survive at lower $\mathrm{pH}$ and has higher redox potential. The principle objective of this study is to bioleach the As from realgar mineral using L. ferriphilum. The impact of energy source (ferrous iron) supplied to the media on the efficiency of As bioleaching was observed. Further, the leaching data were applied to determine the reaction kinetics to measure rate of bioleaching.

\section{MATERIALS AND METHODS}

\subsection{Realgar mineral particles}

A sample of realgar mineral was procured from the mine sector of Lingshot province (Zanskar, India). It was powered by lab jaw crusher followed by ball mill. The grounded ore mineral was sieved to isolate the particle size range from 100 to $1,200 \mu \mathrm{m}$ using standard sieve sets. These selected particles were taken for bioleaching examinations. X-ray diffraction analysis was examined for mineralogical studies to confirm and determine the composition of realgar present in the sample. Quantitative analysis of XRD showed that the mineral sample composed with $12.30 \%$ of stishovite, $68.785 \%$ of realgar, $2.61 \%$ of litharge, $5.78 \%$ of tridymite, $3.748 \%$ of quartz, and $7.223 \%$ of cristobalite.

\subsection{Chemical analysis}

The realgar mineral sample was under taken to chemical analysis for determining the comprised constituents in the ore. The amount of silica, iron, titanium, and manganese present in the mineral was determined spectrophotometerically using the appropriate reagents, ammonium molybdate, 1,10-phenonthroline, hydrogen peroxide, and periodate, respectively. Amount of sulphur was estimated after precipitation as barium sulphate using standard procedure. Amount of calcium was determined by titration method involving EDTA. Flame photometer was used to analyze the amount of sodium and potassium present in the sample. Amount of As present in the realgar was determined by atomic absorption spectrometer.

\subsection{Bacterial strain and media}

The bacterial strain, L. ferriphilum, was used in this study. The strain was isolated from acid mine province at Copper mines province at Chitradurga, India. The bacteria was developed in $9 \mathrm{~K}$ medium comprising $0.5 \mathrm{~g} / \mathrm{L}$ of $\mathrm{K}_{2} \mathrm{HPO}_{4}, 0.5$ $\mathrm{g} / \mathrm{L}$ of $\mathrm{MgSO}_{4} .7 \mathrm{H}_{2} \mathrm{O}, 3.0 \mathrm{~g} / \mathrm{L}$ of $\left(\mathrm{NH}_{4}\right)_{2} \mathrm{SO}_{4}, 0.1 \mathrm{~g} / \mathrm{L}$ of $\mathrm{KCl}$, and $0.01 \mathrm{~g} / \mathrm{L}$ of $\mathrm{Ca}\left(\mathrm{NO}_{3}\right)_{2} .44 .2 \mathrm{~g} / \mathrm{L}$ of $\mathrm{FeSO}_{4} .7 \mathrm{H}_{2} \mathrm{O}$ was added as the energy source. Bacterial enrichment was carried out in the initial $\mathrm{pH}$ value 1.5 at $313 \mathrm{~K}$. Molecular characterization of the strain was found to be $99 \%$ identical to L. ferriphilum. The Nucleotide sequence of isolated L. ferriphilum was deposited in National Centre for Biotechnology Information (NCBI), Maryland, USA. The nucleotide submission was attained the accession number KF743135.

\subsection{Bacterial strain and media}

To enhance the bioleaching rate, isolated L. ferriphilum was adapted to realgar mineral. In order to adapt $15 \%$ (volume /volume) of developed culture was sequentially sub cultured in the $9 \mathrm{~K}$ media with $1 \%(\mathrm{w} / \mathrm{v})$ of powdered realgar. Suitable conditions such as temperature $313 \mathrm{~K}$, initial $\mathrm{pH} 1.5$, and rotation speed of $200 \mathrm{rpm}$ were maintained for proper growth of the culture. Using $\mathrm{H}_{2} \mathrm{SO}_{4}(5 \mathrm{~N})$, the value of initial $\mathrm{pH}$ of the media was adjusted. The adapted L. ferriphilum was used as inoculum for further bioleaching process. Analytical grade chemicals and purified deionized-water were utilized for the bioleaching examinations.

\subsection{Bioleaching experiments}

Experiments for As bioleaching were undertaken in $250 \mathrm{~mL}$ conical flask. Each flask contained $9 \mathrm{~K}$ medium $(90 \mathrm{~mL})$ and well-developed $L$. ferriphilum cells $(10 \mathrm{~mL})$ with initial $\mathrm{pH}$ value of 1.5. The bioleaching process was separated into different five parts. The concentration of $\mathrm{Fe}^{2+}$ was taken that ranging from $2-10 \mathrm{~g} / \mathrm{L}$ in each part. All the conical flasks were agitated at agitation speed $200 \mathrm{rpm}$ with $0.3 \%(\mathrm{w} / \mathrm{v})$ of realgar particles, and the incubation temperature was maintained at $313 \mathrm{~K}$. In addition, a control study was also carried out under the same conditions without addition of bacteria. $\mathrm{HgCl}_{2}(0.2 \mathrm{~g} / \mathrm{L})$ was added as bacterial germicide in the control experiment. Owing to compensate the evaporation loss and to maintain the working of $100 \mathrm{~mL}$ distilled water was added to required volume. Each experiment was conducted in triplicates for a time period of 30 days. The mean values of the triplicates were calculated and expressed as results.

\subsection{Analytical methods}

In the bioleaching process, change in media $\mathrm{pH}$ media and redox oxygen potential were determined at every day using standard $\mathrm{pH}$ meter and platinum electrode with a reference electrode of $\mathrm{Ag} / \mathrm{AgCl}$ [13], respectively. During the process, $5 \mathrm{~mL}$ of the medium sample was collected every 2-day interval and centrifuged at $3500 \mathrm{rpm}$. From the centrifuged solution, the clear solution was separated by Whatman filter paper. This centrifuged clear solution was subjected to determine the leached-out As. Bio-extracted As concentration of in the aqueous solution was determined using atomic absorption spectrometer (PerkinElmer; AA200 model). The efficiency of arsenic extraction, $\mathrm{E}_{\mathrm{As}}(\%)$, was determined from 
the expression $\mathrm{E}_{\mathrm{As}}=\left(N_{\mathrm{s}} / N_{\mathrm{T}}\right) \times 100 \%$. Where, $N_{\mathrm{s}}$ is the concentration of As in the aqueous solution at time $t . N_{\mathrm{T}}$ refers the total available concentration of As in the realgar.

\subsection{Kinetic approaches on realgar bioleaching}

The mathematical equation for first-order reaction can be applied for the As bioleaching, the same is given in Eq. (1).

$r_{\mathrm{As}}=\frac{\mathrm{d} c_{\mathrm{As}}}{\mathrm{d} t}=k_{\mathrm{As}}\left(C_{\mathrm{As}, 0}-C_{\mathrm{As}, t}\right)$

where $k_{\mathrm{As}}$ refers the rate constant for As extraction. While integrating Eq. (1) with the respective limits of time $(t=0 \mathrm{~d}$, $C_{\mathrm{As}, t}=0$ and $t=t \mathrm{~d}, C_{\mathrm{As}, t}=C_{\mathrm{As}, t}$, the outcome relationship between As concentration and time and was obtained [Eq. 2]:

$\ln \left(\frac{c_{\mathrm{AB}, 0}}{c_{\mathrm{As}, 0}-c_{\mathrm{As}, t}}\right)=k_{\mathrm{As}} t$

Eq. (2) is therefore applied for determining the value of $k_{\mathrm{As}}$. $C_{\mathrm{As}, 0}$ and $C_{\mathrm{As}, t}$ are the total concentration of As in the original realgar ore and concentration of As in leached clear solution at the time $t$. From the bioleaching data, using Eq. (2), a plot of $\ln \left(C_{\mathrm{As}, 0} /\left(C_{\mathrm{As}, 0}-C_{\mathrm{As,t},}\right)\right)$ vs time was created that provides the $k_{\mathrm{As}}$ value as slope. Using the kinetic analysis, the rate controlling step was determined through the shrinking core model (SCM) analysis. In SCM analysis, the expressions for rate control by ash layer diffusion and rate control by chemical reaction were developed and given by Eqs. (3) and (4), respectively:

$$
\begin{gathered}
\left.1+2\left(1-X_{\mathrm{As}}\right)-3\left(1-X_{\mathrm{As}}\right)^{2 / 3}=K_{\mathrm{ob}} t----X_{\mathrm{As}}\right)^{1 / 3}=k_{\mathrm{ob}} t-----(4) \\
1-(1)
\end{gathered}
$$

Where $X_{\mathrm{As}}$ refers the fraction of bio extracted As in the aqueous solution. $k_{\mathrm{ob}}$ is observed constant $\left(\mathrm{time}^{-1}\right)$ for the respective model. From the observed plots, $1+2\left(1-X_{\mathrm{As}}\right)-3\left(1-X_{\mathrm{As}}\right)^{2 / 3} v s$ time and $1-\left(1-X_{\mathrm{As}}\right)^{1 / 3} v s$ time, the rate-controlling step was determined based on the regression analysis.

\section{RESULTS AND DISCUSSION}

\subsection{Chemical analysis of realgar}

The chemical analysis of realgar showed that raw ore was composed with different constituents as follows (\% in w/w): As, 69.2\%; $\mathrm{Fe}_{2} \mathrm{O}_{3}, 1.12 \%$; S, 19.1\%; $\mathrm{MgO}, 8.85 \%$; $\mathrm{K}_{2} \mathrm{O}$, $0.10 \% ; \mathrm{Na}_{2} \mathrm{O}, 0.15 \% ; \mathrm{TiO}_{2}, 0.11 \% ; \mathrm{SiO}_{2}, 10.35 \%$; and $\mathrm{MnO}$, $0.41 \%$. From the analysis, it has been interpreted that the As consisted at maximum quantity of the mineral.

\section{$3.2 \mathrm{pH}$ and redox potential values during bioleaching}

Figure 1 shows the value of $\mathrm{pH}$ observed in the leachate during biological leaching process. In the control experiment, there was a minimal decrease in $\mathrm{pH}$ (1.5-1.46) because the mineral sulphides were chemically oxidized. The $\mathrm{pH}$ value increased primarily from 1.51 to $2.52,2.6,2.76,2.4$, and 2.1 in the studies in which the ferrous concentration was varied from $2,4,6,8$, and $10 \mathrm{~g} / \mathrm{L}$, respectively. This $\mathrm{pH}$ increases mainly because of the consumption of acid by the realgar.
After the second day, the gradual decrement in the medium $\mathrm{pH}$ was observed. This decrement in the $\mathrm{pH}$ was occurred because of the production of sulphuric acid in the medium by the oxidation of components present in the ore [14]. At the end of the experiment the $\mathrm{pH}$ was reduced to $1.52,1.51,1.55$, 1.49 , and 1.48 in the media containing $2,4,6,8$, and $10 \mathrm{~g} / \mathrm{L}$ of $\mathrm{Fe}(\mathrm{II})$, respectively.

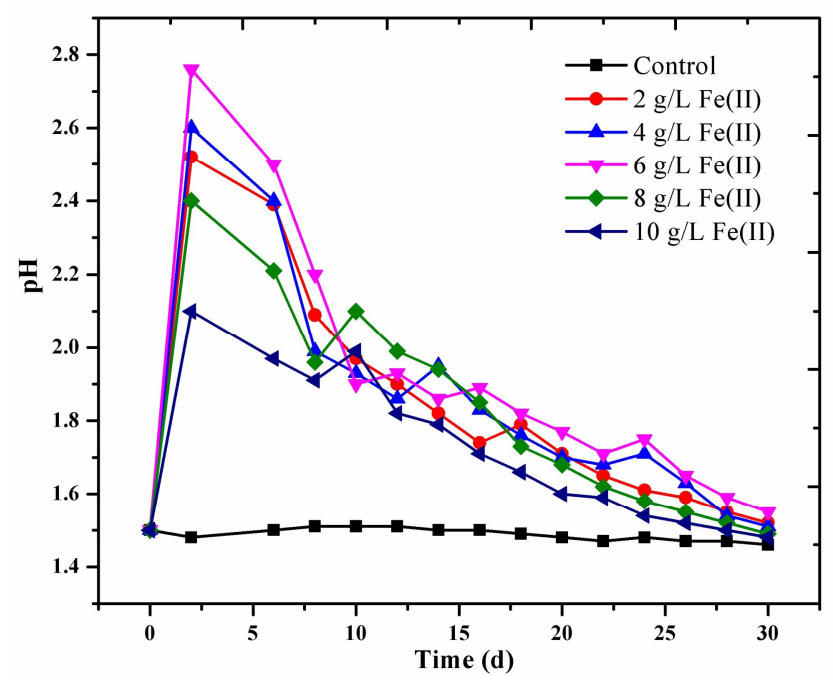

Figure 1: The variation of $\mathrm{pH}$ at different concentrations of $\mathrm{Fe}$ (II) during bioleaching

Figure 2 shows the observations of redox oxygen potential during the As bioleaching. The increment on redox oxygen potential values from $202 \mathrm{mV}$ to $656 \mathrm{mV}$ against $\mathrm{Ag} / \mathrm{AgCl}$ was steady with the $\mathrm{Fe}(\mathrm{III}) / \mathrm{Fe}$ (II) ratio in the bacterial inoculated flasks whereas the ROP value remained constant $(200 \mathrm{mV})$ as against $\mathrm{Ag} / \mathrm{AgCl}$ in the control experiment. The maximum ROP value of $656 \mathrm{mV}$ was observed in the flask containing 6 $\mathrm{g} / \mathrm{L}$ of $\mathrm{Fe}(\mathrm{II})$ concentration. This peak for ROP value was found to be high because of the bio-oxidation of $\mathrm{Fe}$ (II) to $\mathrm{Fe}$ (III) and maintenance of dissolved state of $\mathrm{Fe}$ (III) was well supported at $6 \mathrm{~g} / \mathrm{L}$ of $\mathrm{Fe}(\mathrm{II})$ [15].

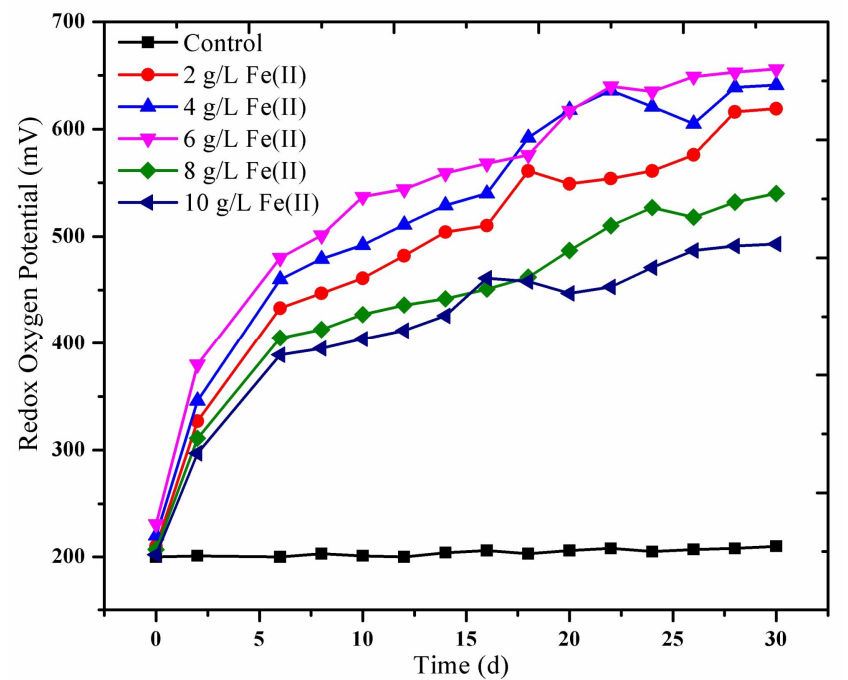

Figure 2: The variation of ROP at different concentrations of $\mathrm{Fe}$ (II) during bioleaching 


\subsection{Effect of ferrous concentration on As bioleaching and kinetics}

As bioleaching by $L$. ferriphilum at various ferrous iron concentrations with respect to time is presented in Figure 3. During the experiments, at the control, As was leached about $5.4 \%$ after 30 days. However, bio-extraction of As were reached $68.39,72.22,75.52,64.61$ and $59.37 \%$ in the flasks containing 2, 4, 6, 8 and $10 \mathrm{~g} / \mathrm{L}$ of $\mathrm{Fe}(\mathrm{II})$, respectively. It cleared that the extraction is much associated with concentration of $\mathrm{Fe}(\mathrm{II})$ [16]. The experiment results evident that the concentration of $6 \mathrm{~g} / \mathrm{L}$ for Fe(II) could be an optimal energy source input for the $9 \mathrm{~K}$ media to the bioleaching process using $L$. ferriphilum to attain the improved efficiency. The speed of bioleaching in term of leaching rate can be explained as rate constant $\left(k_{\mathrm{As}}\right)$. Figure 4 depicts a fitting of leaching data to observe the rate kinetic constant values for different $\mathrm{Fe}(\mathrm{II})$ concentrations [17]. The corresponding values of regression coefficient $\left(R^{2}\right)$ for the data fitting is given in Table 1. Since the leaching is positively associated with $\mathrm{Fe}(\mathrm{II})$ concentration, the rate constant value also increases with increase in the $\mathrm{Fe}(\mathrm{II})$ concentration until $6 \mathrm{~g} / \mathrm{L}$. In the experiments with $2,4,6,8$, and $10 \mathrm{~g} / \mathrm{L}$ of $\mathrm{Fe}(\mathrm{II})$, the values of rate constant were found to be $1.1144,1.2801$, $1.3633 \mathrm{~d}, 1.0026,0.9130 \mathrm{~d}^{-1}$, respectively. It is clear that, with the optimum $\mathrm{Fe}(\mathrm{II})$ concentration of $6 \mathrm{~g} / \mathrm{L}$, As leaching was enhanced and reaches maximum rate. The empirical models of ALDC and CRC were examined to determine the rate-controlling mechanism based on SCM [18]. The graphical fittings of SCM on experimental data was given in Figures $5 \mathrm{a}$ and $5 \mathrm{~b}$. From the regression values, it clears that the leaching data fit much better to the ash layer diffusion model.

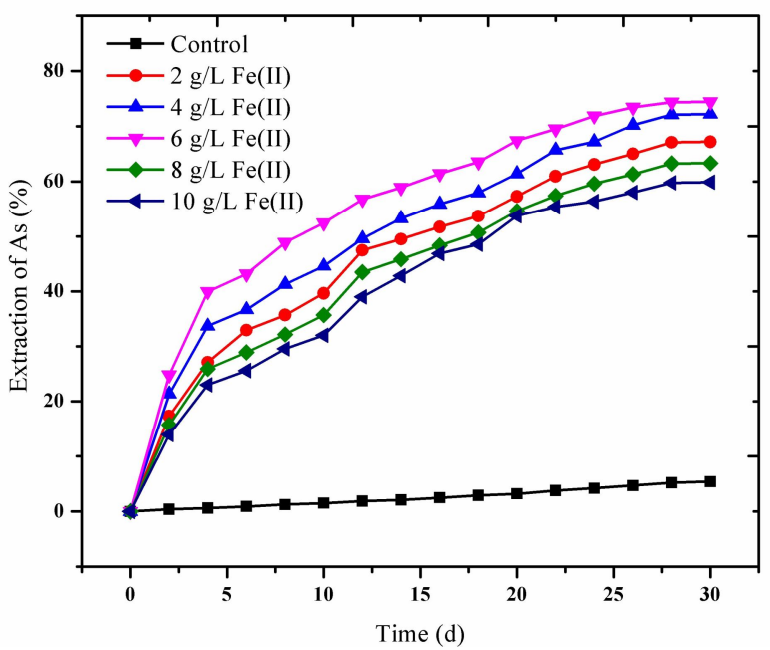

Figure 3: Bioleaching efficiency of As with different concentrations of $\mathrm{Fe}(\mathrm{II})$

Table 1: Regression Coefficient value of SCM Models

\begin{tabular}{|c|c|c|}
\hline \multirow{2}{*}{$\begin{array}{l}\text { Concentration } \\
\text { (g/L) of } \\
\mathrm{Fe}(\mathrm{II})\end{array}$} & \multicolumn{2}{|c|}{$\mathrm{R}^{2}$ value } \\
\hline & Diffusion by & Controlled by \\
\hline
\end{tabular}

\begin{tabular}{ccc}
\cline { 2 - 3 } & $\begin{array}{c}\text { Ash layer } \\
\text { Control }\end{array}$ & $\begin{array}{c}\text { Chemical } \\
\text { Reaction }\end{array}$ \\
\hline 2 & 0.9914 & 0.8627 \\
4 & 0.9929 & 0.8359 \\
6 & 0.983 & 0.6958 \\
8 & 0.9878 & 0.877 \\
10 & 0.9784 & 0.8993 \\
\hline
\end{tabular}

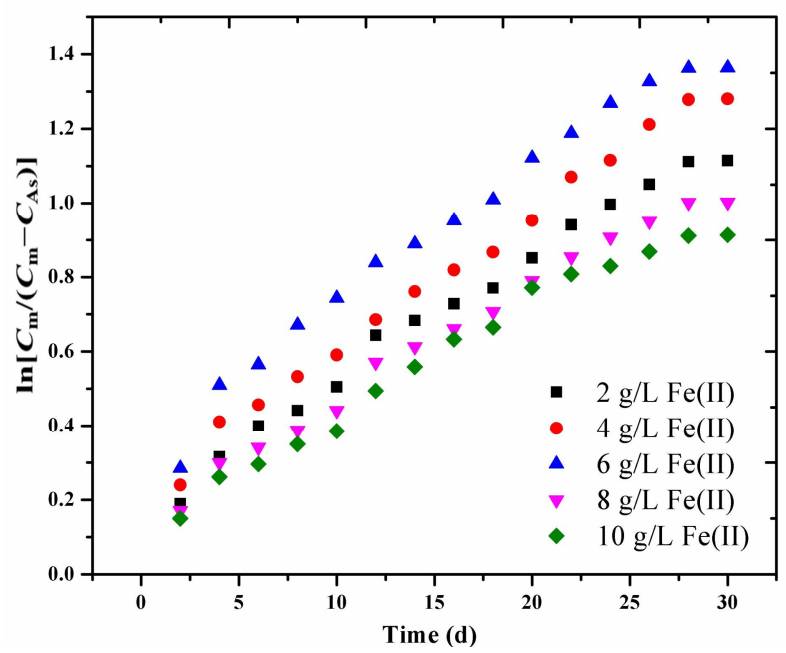

Figure 4: Graphical fitting for value of rate constant at various $\mathrm{Fe}(\mathrm{II})$ concentrations.
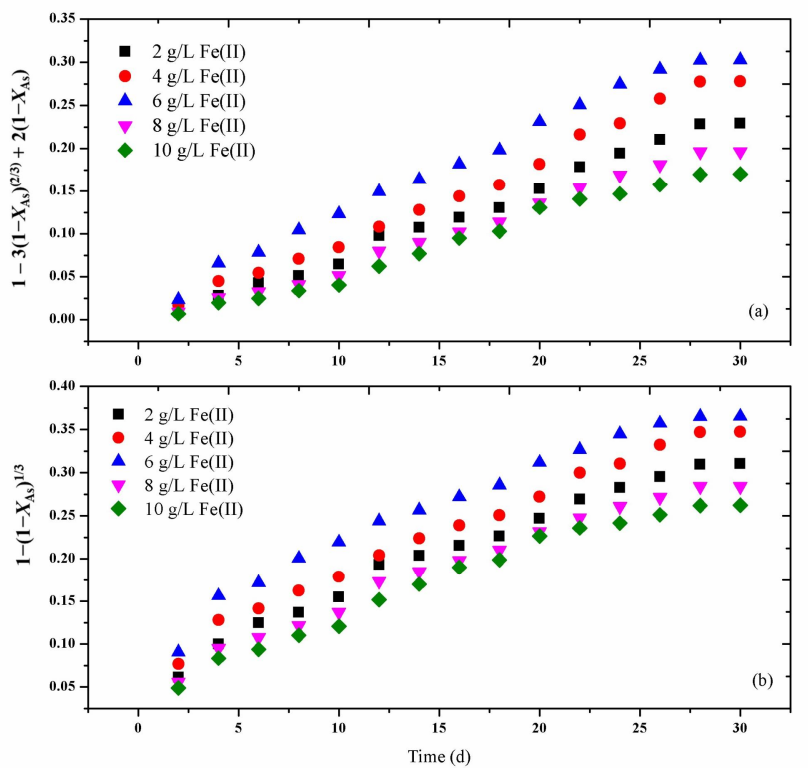

Figure 5: Plot of extraction data to (a) model for ash layer and (b) model for chemical reaction control

\section{CONCLUSIONS}

A study on the effect of energy source on bioleaching of As from realgar ore using L. ferriphilum was carried out. The experimental results showed that the bioleaching process is positively correlated to the concentration of ferrous sulphate used as energy source in the media. Minimum bioleaching efficiency of $67.19 \%$ was achieved when the experiment was conducted in the conditions such as initial $\mathrm{pH} 1.5$, agitation speed $200 \mathrm{rpm}$, temperature $298 \mathrm{~K}$ and concentration of Fe(II) 
$1 \mathrm{~g} / \mathrm{L}$. Bioleaching efficiency was observed to be significantly increasing when $\mathrm{Fe}(\mathrm{II})$ concentration was increased. Maximum bioleaching efficiency $74.42 \%$ was observed when $6 \mathrm{~g} / \mathrm{L}$ of $\mathrm{Fe}(\mathrm{II})$ was used for the experiment at the end of 30 days. The maximum rate constant value was found to be $1.3633 \mathrm{~d}^{-1}$ in the flask containing $6 \mathrm{~g} / \mathrm{L}$ of $\mathrm{Fe}(\mathrm{II})$. From the SCM analysis, it was evident that the bioleaching rate is controlled by ash layer diffusion.

\section{ACKNOWLEDGEMENT}

The authors are grateful to management of Addis Ababa Science and Technology University, Addis Ababa, Ethiopia.

\section{REFERENCES}

1. S. Venkatesa Prabhu, R. Baskar, T.A Amare, A.K Gizachew, and G. Amsalu, Effect of FE(II) Concentration on Bioleaching of Zinc from Sphalerite using Leptospirillum Ferriphilum: Kinetic Aspects. International Journal of Engineering and Advanced Technology. Vol. 9, no.1, pp.1492 - 1498, October 2019.

2. A. H. Kaksonen, C. Morris, S. Rea, J. Li, K. M. Usher, R. MvDonald, F. Hilario, T. Hosken, M. Jackson, C. du Plessis A, Biohydrometallurgical iron oxidation and precipitation: PartII-Jarosite precipitates characterisation and acid recovery by conversion to hematite. Hydrometallurgy, Vol. 147, no.8, pp. 264-272, August 2014.

3. S. Venkatesa Prabhu, R. Baskar, R. Natesan, R. Kavitha, Bioleaching of $\mathrm{Zn}$ from sphalerite using Leptospirillum ferriphilum isolate: effect of temperature and kinetic aspects. Applied Biological Chemistry, Vol.63, no.44, August 2020.

4. E. Darezereshki, M. Schaffie, M. Lotfalian, S. A. Seiedbaghery, M. Ranjbar, Use of mesophilic and thermophilic bacteria for the improvement of copper extraction from a low-grade ore. International Journal of Minerals, Metallurgy and Materials, Vol. 18, no. 2, pp.138-142, April 2011.

5. C. Santhosh, K. H. Kishore, G. P. Lakshmi, G. Kushwanth, P. R. K. Dharma Teja, R. S. E. Ravindran, S. V. Cheerala, M. R. Kumar, Detection of Heavy Metal Ions using Star-Shaped Microfluidic Channel. International Journal of Emerging Trends in Engineering Research, Vol. 7, no.12, pp. 768-771, December 2019.

6. S. R. Dave, K. H. Gupta, and D. R. Tipre, Characterization of arsenic resistant and arsenopyrite oxidizing Acidithiobacillus ferrooxidans from Hutti gold leachate and effluents. Bioresource Technology, Vol. 99, no. 3, pp.7514-7520, March 2008.

7. L. Falco, C. Pogliani, G. Curutchet, E. Donati, A comparison of bioleaching of covellite using pure cultures of Acidithiobacillus ferrooxidans or a mixed culture of Leptospirillum ferrooxidans and
Acidithiobacillus thiooxidans. Hydrometallurgy, Vol. 71, no.2, pp. 31-36, October 2003.

8. S. Venkatesa Prabhu, R. Baskar, R. Gurusamy, T. A. Amare, Bioleaching of Zinc and Iron from Sphalerite Using Leptospirillum Ferriphilum: Kinetic Aspects. International Journal of Scientific \& Technology Research, Vol. 8, pp. 1293-1300, no. 11, November 2019.

9. A. Giaveno, L. Lavelle, P. Chiacchiarini, E. Donati, Bioleaching of Zinc from low-grade complex sulphide ores in an airlift by isolated Leptospirillum ferrooxidans. Hydrometallurgy, Vol. 89, pp. 117-126 March 2007.

10. N. V. S. Pavan Kumar, J. K. R. Sastry, K. S. Rao, Mining Negative Frequent regular Itemsets from Data Streams. International Journal of Emerging Trends in Engineering Research, Vol. 7, no.8, pp. 85-98, December 2019.

11. $\mathrm{H}$. Cheng and $\mathrm{Y}$. Hu, Bioleaching of anilite using pure and mixed culture of Acidithiobacillus ferrooxidans and Acidithiobacillus caldus. Mineral Engineering, Vol. 20, pp.1187-1190, October 2007.

12. G. H. Jeffery, J. Bassett, J. Mendham, R. C. Denney, Vogel's textbook of quantitative chemical analysis, Fifth edition, Longman Group UK Limited, London, pp.845-881, 1989.

13. J. Zhang, X. Zhang, Y. Ni, X. Yang, H. Li, Bioleaching of Arsenic from medicinal realgar by pure and mixed cultures. Process Biochemistry, Vol. 42, pp.1265-1271, September 2007.

14. D. P. Lu, Q. Wang, Current Study of APL treatment in China. Int J Hematol, Vol. 76, pp.316-325, January 2002.

15. S. M. Mousavi, A. Jafri, S. Yaghmaei, M. Vossoughi, R. Roostaazad, Bioleaching of low-grade Salpharite using a column reactor. Hydrometallurgy, Vol. 82, pp.75-82, July 2006.

16. P. Guo, G. Zhang, J. Cao, Y. Li, Z. Fang, C. Yang, Catalytic effect of $\mathrm{Ag}^{+}$and $\mathrm{Cu}^{+}$on leaching realgar $\left(\mathbf{A s} \mathbf{s}_{2} \mathbf{S}_{2}\right)$. Hydrometallurgy, Vol. 106, pp. 99-103. February 2011.

17. P. Zhu, Z. Xin-jiong, L. Kun-fang, Q. Guang-ren, M. Zhou, Kinetics of leaching refractory gold ores by ultrasonic-assisted electro-chlorination. International Journal of Minerals, Metallurgy and Materials, Vol. 19, pp.473-481, June 2012.

18. A. Rubio, F.J. Garcia Frutos, Bioleaching capacity of an extremely thermophilic culture for chalcopyritic materials. Mineral Engineering, Vol. 15, pp.689-694, September 2002. 